\title{
Yoga and Cardiovascular Disease
}

\author{
Jawahar L Mehta*, Paulette Mehta and Balakrishna V Pai \\ University of Arkansas for Medical Sciences and the Central Arkansas Veterans Healthcare System, USA
}

Submission: June 22, 2017; Published: September 21, 2017

*Corresponding author: Jawahar L Mehta, University of Arkansas for Medical Sciences, 4301 W. Markham, Slot 532, Little Rock, AR 72212, USA, Email: MehtaJL@UAMS.edu

\section{Abstract}

Many common medical conditions, such as myocardial ischemia, hypertension and diabetes mellitus, are caused or exacerbated by stress. The prevalence of stress is increasing with greater financial instability, job insecurity, aging of the population and breakdown of societal values. One way to control stress is through mind-body relaxation therapies which are accessible to a large segment of the public. These therapies cost very little and have few, if any, side effects. Yoga is a mind-body relaxation technique that has been used for thousands of years in the East, and is emerging as a preventative and therapeutic tool in the West. In this review, we discuss different types of yoga and how the practice of yoga can modify coronary heart disease (CHD) risk factors, including high blood pressure, dyslipidemia and insulin resistance. We analyze clinical trials in a variety of patients. We discuss the use of yoga practice in special populations such as the elderly. Finally, we discuss limitations of these studies, including publication bias in favor of positive over negative studies, as well as difficulty in choosing and evaluating control subjects. Despite these limitations, preponderance of evidence suggests a salutary effect of yoga in most subjects with diseases induced or exacerbated by stress.

Abbreviations: RCT: Randomized Controlled Trial; BP: Blood Pressure; LSM: Lifestyle Management; LVEF: Left Ventricular Ejection Fraction; RCT: Randomized Controlled Trial; QOL: Quality of Life; DM: Diabetes Mellitus; HbA1C: Hemoglobin A1C; RCT: Randomized Controlled Trial

\section{Introduction}

Hypertension, diabetes, dyslipidemia and obesity affect heart, kidney, brain and peripheral circulation. These conditions are the most common causes of morbidity and mortality in developing countries, and all or one of these conditions are/is present in more than $50 \%$ of the population over 50 years of age [1]. Psychosocial stress is a major contributor to coronary heart disease (CHD), both in its genesis and outcome. Observational studies have shown that patients with CHD who are lonely, hopeless, helpless and despondent do worse compared to those who feel at ease with their surroundings [1]. Mental stress is associated with production of harmful chemicals and hormones that affect the cardiovascular system adversely. Therefore, it can be surmised that interruption of stress response may be beneficial in healing the cardiovascular system. The US Congress established the National Center for Alternative Medicine under the umbrella of National institute of Health to study the benefits of alternate therapies, like yoga, deepbreathing exercises, hypnotherapy, progressive relaxation and tai chi. Here, we discuss the possible benefits of yoga in CHD and associated conditions.

\section{Yoga and its components}

The word yoga has been described as action leading to the union of the body and the mind which improves physical, mental and spiritual well being. It is an ancient art of mind-body control that originated in India over five thousand years ago and is now widely popular throughout the world. The National Health Statistics report that about 21 million adults living in the United States use yoga as a complementary health approach [2]. Pathanjali is considered father of modern yoga. He described eight components (limbs) of yoga: Yama (moral behavior), Niyama (healthy habits), Asana (postures), Pranayama (breathing exercises), Pratyahara (sensory-motor activity withdrawal), Dharana (contents of the mind), Dhyana (contemplation), and Samadhi (higher consciousness).

There are many schools of yoga with varying emphasis on the basic components including breathing, postures and meditation Table 1. These three components are inter-related and bring out awareness of the present, as well as help in coordination of the body and the mind. In the United States, Hatha yoga or its variations are the most common practiced versions of yoga at present, although many years ago, transcendental meditation was very common. 
Table 1: Meditation.

\begin{tabular}{|c|c|}
\hline Types & Involves \\
\hline Focused meditation & Sitting in a comfortable position \\
\hline Activity oriented meditation & $\begin{array}{c}\text { Observe the thought without engaging } \\
\text { it }\end{array}$ \\
\hline Mindfulness meditation & $\begin{array}{l}\text { Awareness of breath, thought, } \\
\text { sensations }\end{array}$ \\
\hline \multirow[t]{2}{*}{ Spiritual meditation } & Present moment awareness \\
\hline & $\begin{array}{l}\text { Purify the mind by removing the errors } \\
\text { in perception, habitual reaction, and } \\
\text { mind modification and developing } \\
\text { wise course of action (wisdom) }\end{array}$ \\
\hline
\end{tabular}

\section{Yoga and its role in body-mind relationship}

Physical benefits of yoga arise directly from conscious physical movement of the body that results in mental relaxation. Wellexecuted postures result in a state of "restful awareness" of the body. Routine and proper stretching leads to proper toning of skeletal muscles. Regulation of breathing is under the control of both the conscious and the unconscious mind, and hence yoga regulates and improves the quality and rhythmicity of breathing. Since breathing is essential for oxygen diffusion and dissemination, its regulation results in better oxygenation of tissues and improve health, memory, actions and survival.

Mental benefits of yoga are far more reaching than the physical benefits. Mind senses the environment through 6 sensory organs; eyes, ears, tongue, skin, nose and mind. The first 5 sensory organs depend upon the current input from these organs for the sensations; whereas the mind functions differently. The proper functioning of mind involves consciousness, perception, sensation and reaction. Mind regulates perception, memory, imagination and sleep and various permutations and combinations, such as emotion, feeling, opinion, judgment, craving and aversion. Body reacts to these mental phenomena based on past events (preconditioning). This response occurs instantaneously through memory. Past memory elicits bodily response; for example, angry thoughts induce release of various stress hormones. Similarly, fear can result in panic (flight or fight). Bodily responses are amplified by repeated reentry cycles of thought in a positive feedback fashion. Through gentle and repetitive "awareness" and "calming the mind", this feedback loop of bodily reaction and thought process can be altered significantly by yoga. This interruption of the feed-back loop is a major goal of yoga (mindful meditation) [3]. Spiritual benefits of yoga include improved understanding of ourselves and others. This, in turn, promotes harmony within a relationship. Past mental impressions influence our current perception of physical events that trigger new bodily reactions. For example, seeing a rope in [4] darkness can evoke memory of a snake and instantaneously provoke fear and release of catecholamines. Seeing a friend walking in the hallway without smiling can produce thoughts that may not be accurate. This "Inner chatter" can be harmful to the body due to constant release of catecholamines and activation of dopaminergic receptors [1].
Meditation or the restful phase of yoga brings to light subtle "mind" phenomena that may provide one an opportunity to adjust the thought process and behavioral response. This is the fundamental goal of the practice of yoga. Importantly, "soothing of mind" can be achieved through slow repetitive breathing and mindful awareness which reduces "inner chatter" based on misperceptions.

\section{Mechanisms of benefits of yoga}

There are marked abnormalities in the neurohormonal system in a variety of disease states. Most dramatic examples of heightened neuronal adrenergic activity or disrupted receptor function are heart failure, acute myocardial ischemia, hypertension, coronary artery vasospasm and post-operative arrhythmias [1]. The levels of catecholamines correlate with the outcome of patients with heart failure and cardiac arrhythmias. In 1980, Sheridan et al. [5] showed a correlation between alpha adrenergic activity and dysrhythmias during myocardial ischemia and reperfusion in cats. Lanza et al. [6] showed a relationship between stress-induced myocardial perfusion defects and coronary microvascular dysfunction in patients with cardiac syndrome X. Abnormal neurohormone status has been thought to contribute to myocardial ischemia and QT prolongation in patients with strokes or space occupying lesions in the brain [7]. Similar abnormal mind-body response has been identified in many illnesses, such as asthma, meno-metrorrhagia, thyroid disorders, inflammatory bowel disease, and several other conditions [8].

In a review on the physiology of yoga, Jevning et al. [9] called the state of mindful awareness a "wakeful hypometabolic integrated response". They suggested that yoga meditation is an integrated signal from the central nervous system that controls circulatory and metabolic functions. Meditation is concomitantly a relaxed as well as an alert state such that it is likely that cardiac output and cerebral blood flow both probably increase during meditation. The practice of yoga induces significant alterations in neurohormonal system resulting in improved electrophysiological activity of the brain. Studies using high resolution brain imaging have shown that the activity in the frontal and other cortical brain regions is reduced, while activity in the limbic brain areas increases, especially in the hippocampus, during meditation [9]. The hippocampus is the area associated with the stress hormone cortisol. Bremmer [1012] reported that patients with post-traumatic stress disorder or depression have smaller hippocampus that may relate to increased stress-induced cortisol levels. He actually showed that meditation actually increases the hippocampus size. Meditation induces relaxation of the body and the limbic system resulting in a feeling of motivation, satisfaction, energy and potential. The physiological benefits of yoga in the cardiovascular system can be ascribed primarily to a decrease in catecholamine release and activity resulting in lower blood pressure and heart rate. During meditation, the parasympathetic nervous system is activated, resulting in a balanced sympathetic-parasympathetic axis. Other biochemical alterations associated with the practice 
of yoga include a decrease in urinary homovanillicmandelic acid, blood lactic acid and body temperature, and an increase in betaendorphins and galvanic skin response (measure of decreasing sympathetic nervous activity). [1,13] During yoga meditation, there is a marked reduction in carbon dioxide generation by skeletal muscles, a 5-fold increase in plasma arginine vasopressin levels and synchrony of electroencephalographic signals [14]. Some investigators have suggested that there is a change in melatonin production with yoga practice [15]. These biochemical and metabolic alterations during yoga practice result in dilatation of pupils, a decrease in pulse and respiratory rates, and a small but significant reduction in blood pressure [16-18]. Innes et al. [19] assessed 70 published studies, and observed a marked benefit of yoga practice on cardiac risk factors, especially glucose intolerance and insulin sensitivity, lipid profile, blood pressure, oxidative stress, coagulation, and cardiovagal function. A regular practice of yoga reduces body mass index, total-and low density lipoprotein-cholesterol, fibrinogen and blood pressure. In one study conducted in residents of a yoga retreat [20], a significant reduction in urinary excretion of epinephrine, norepinephrine, dopamine and aldosterone as well as serum testosterone and luteinizing hormones, and an increase in cortisol excretion were observed.

\section{Clinical trials of yoga}

Yoga has been studied extensively in subjects with hypertension, dyslipidemia, diabetes, obesity and/or CHD. There are also some studies on the effect of yoga in patients with metabolic syndrome. Most of the early reports on the effects of yoga on the cardiovascular system came from the Indian literature; since then many well-controlled studies have been conducted in US and the UK. Many studies are anecdotal in nature or represent small single-arm studies, yet many studies represent important randomized, controlled trials.

\section{Yoga in patients with hypertension}

Table 2: Major trials of yoga in patients with hypertension.

\begin{tabular}{|c|c|c|}
\hline $\begin{array}{c}\text { Type of study } \\
\text { (ref \#) }\end{array}$ & Intervention & Results \\
\hline Single arm [21] & $\begin{array}{c}\text { Yoga and } \\
\text { biofeedback for 6 } \\
\text { weeks) }\end{array}$ & $\begin{array}{c}\text { Yoga decreased blood } \\
\text { pressure as well as need for } \\
\text { medications }\end{array}$ \\
\hline $\begin{array}{c}\text { Single arm study } \\
{[22]}\end{array}$ & $\begin{array}{c}\text { Yoga + } \\
\text { biofeedback 9-12 } \\
\text { months }\end{array}$ & $\begin{array}{c}\text { Pressor responses to } \\
\text { emotional and physical } \\
\text { stimuli were less in Yoga } \\
\text { group }\end{array}$ \\
\hline RCT [23] & $\begin{array}{c}\text { Yoga vs. relaxation } \\
\text { for 6 weeks }\end{array}$ & $\begin{array}{c}\text { Yoga was more effective than } \\
\text { relaxation }\end{array}$ \\
\hline $\begin{array}{c}\text { Case control } \\
\text { observation [24] }\end{array}$ & $\begin{array}{c}\text { Raja Yoga, single } \\
\text { session in short } \\
\text { \& long term yoga } \\
\text { practitioners vs. } \\
\text { non practitioners }\end{array}$ & $\begin{array}{c}\text { Yoga group had lower } \\
\text { diastolic blood pressure, } \\
\text { heart rate and total } \\
\text { cholesterol }\end{array}$ \\
\hline
\end{tabular}

\begin{tabular}{|c|c|c|}
\hline RCT [25] & $\begin{array}{c}\text { Yoga vs. Drugs }+ \\
\text { Relaxation for 11 } \\
\text { weeks }\end{array}$ & $\begin{array}{c}\text { Yoga and drugs controlled } \\
\text { blood pressure similarly; } \\
\text { yoga and relaxation had } \\
\text { similar effects on blood } \\
\text { pressure }\end{array}$ \\
\hline RCT [50] & $\begin{array}{c}\text { Yoga lifestyle } \\
\text { for 20 weeks vs. } \\
\text { standard care }\end{array}$ & $\begin{array}{c}\text { Blood pressure improved } \\
\text { more in the Yoga group }\end{array}$ \\
\hline
\end{tabular}

Some important studies of yoga in patients with hypertension are shown in Table 2. Patel [21-23] conducted early studies of yoga in hypertensive subjects. Patel \& North [23] conducted a randomized trial of yoga practice in 34 subjects who were less than 75 years old and had a diastolic blood pressure of $110 \mathrm{~mm} \mathrm{Hg}$ or higher. Patients were randomized to yoga practice or to general relaxation exercises, and all were evaluated every 2 weeks for 3 months. Patients in both groups had a significant drop in systolic and diastolic blood pressures. However, subjects in the yoga group had a much greater drop in blood pressure. Whether this benefit would be sustained when the practice of yoga is stopped was not evaluated.

In another study by Harinath et al. [15] hypertensive patients were randomly divided in two groups; group 1 subjects served as control and performed body flexibility exercises for 40 minutes and slow running for 20 minutes during morning hours and played sports for 60 minutes during evening hours daily for 3 months; group 2 subjects practiced selected yogic asanas (postures) for 45 minutes and pranayama. The benefit of yoga practice in terms of blood pressure reduction was modest, but statistically significant; in contrast the control group had no significant change in blood pressure. Similar effects of yoga practice on blood pressure and heart rate were identified by Vyas \& Dikshit [24]. Murugesan et al. [25] randomized hypertensive patients, age 35 and 65 years to yoga practice, medications alone, or no treatment. Patients in the yoga group performed breathing exercises, Asanas as well as meditation for 1 hour every day for 11 weeks. There was a significant decrease in systolic blood [26,27] pressure, heart rate and body weight; and these changes were greater in subjects who practiced yoga than in the subjects who received medications alone.

\section{Yoga in patients with coronary heart disease}

There are many trials of yoga in subjects with CHD; several of these trials were large and randomized, and all showed consistent and significant benefit. Methodologies used in these studies were not similar, and most patients who received yoga training had other aggressive lifestyle changes as well, including change in diet, exercise plan, and cessation of smoking. Major trials of yoga in patients with CHD are shown in Table 3 [28-30]. In the earliest of these lifestyle modification studies conducted in the United States, those by Ornish et al or based on Ornish lifestyle modification regimen [31-33] are particularly noteworthy. Patients with CHD who received comprehensive program of lifestyle changes (yoga, dietary modification and weight control) had fewer angina attacks, experienced less stress, and their serum 
total cholesterol and body weight fell. In the most widely cited Lifestyle Heart Trial [34], patients with CHD were assigned to an experimental group (very low-fat vegetarian diet, discontinuation of smoking, stress management training and moderate exercise) or to a usual-care control group for 1 year. The most dramatic finding was regression in coronary artery stenosis from $40 \%$ to $38 \%$ in the experimental group, whereas it progressed from $43 \%$ to $46 \%$ in the control group. Most importantly, the experimental group experienced a significant decrease in blood pressure and a decline in the frequency of angina attacks, while both blood pressure and angina frequency increased in the control group.

Table 3: Effects of yoga in subjects with coronary heart disease.

\begin{tabular}{|c|c|c|}
\hline Type of Study (ref \#) & Intervention & Results \\
\hline $\begin{array}{l}\text { Observational study } \\
\qquad[24]\end{array}$ & $\begin{array}{l}\text { Raja Yoga, single } \\
\text { session in short and } \\
\text { long term vs. non } \\
\text { yoga practitioners }\end{array}$ & $\begin{array}{l}\text { Yoga group had } \\
\text { lower diastolic BP, } \\
\text { heart rate, lower } \\
\text { cholesterol }\end{array}$ \\
\hline Single arm [25] & $\begin{array}{l}\text { Asanas, pranayamas, } \\
\text { relaxation and group } \\
\text { support for } 10 \text { days }\end{array}$ & $\begin{array}{l}\text { Improvement in } \\
\text { blood lipids and sugar }\end{array}$ \\
\hline RTC [28] & $\begin{array}{l}\text { Yoga and LSM vs. } \\
\text { traditional cardiac } \\
\text { rehabilitation } \\
\text { program for } 12 \\
\text { months }\end{array}$ & $\begin{array}{l}\text { Angina frequency } \\
\text { decreased in the } \\
\text { Yoga plus LSM group, } \\
\text { but carotid intima } \\
\text { thickness stayed } \\
\text { same }\end{array}$ \\
\hline RCT [29] & $\begin{array}{l}\text { Yoga and LSM vs. } \\
\text { traditional cardiac } \\
\text { rehabilitation for } 6 \\
\text { months }\end{array}$ & $\begin{array}{l}\text { Improvement in } \\
\text { psychosocial and QOL } \\
\text { measurements with } \\
\text { Yoga and LSM }\end{array}$ \\
\hline Single arm [30] & $\begin{array}{l}\text { Yoga and meditation } \\
\text { for } 6 \text { weeks }\end{array}$ & $\begin{array}{l}\text { Patients had } \\
\text { reduction in BP, } \\
\text { heart rate, body } \\
\text { mass. Patients with } \\
\text { CHD had improved } \\
\text { endothelial function }\end{array}$ \\
\hline $\begin{array}{l}\text { Observational study } \\
\qquad[31]\end{array}$ & $\begin{array}{l}\text { Yoga and LSM plus } \\
\text { standard treatment } \\
\text { for } 6 \text { months }\end{array}$ & $\begin{array}{l}\text { Yoga and LSM } \\
\text { group had greater } \\
\text { improvements in } \\
\text { CHD risk factors than } \\
\text { other group }\end{array}$ \\
\hline RCT [33] & $\begin{array}{l}\text { Yoga and LSM plus } \\
\text { standard treatment } \\
\text { vs. usual care for } 1 \\
\text { year }\end{array}$ & $\begin{array}{l}\text { Yoga and LSM group } \\
\text { had regression } \\
\text { of coronary } \\
\text { atherosclerosis at } 1 \\
\text { year }\end{array}$ \\
\hline RCT [34] & $\begin{array}{l}\text { Yoga and LSM vs. } \\
\text { usual care for } 24 \text { days }\end{array}$ & $\begin{array}{l}\text { Yoga and LSM had } \\
\text { improved exercise } \\
\text { tolerance and } \\
\text { increase in LVEF of } \\
6 \%\end{array}$ \\
\hline RCT [35] & $\begin{array}{l}\text { Yoga, control of risk } \\
\text { factors, diet and } \\
\text { exercise vs. control } \\
\text { group for } 1 \text { year }\end{array}$ & $\begin{array}{l}\text { Yoga group had } \\
\text { less angina, more } \\
\text { weight loss, fewer } \\
\text { interventions and } \\
\text { more regression } \\
\text { of coronary } \\
\text { atherosclerosis }\end{array}$ \\
\hline
\end{tabular}

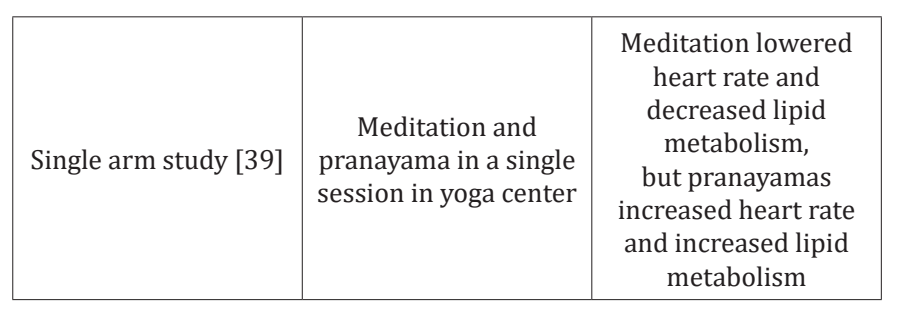

In another study in CHD patients reported by Ornish et al. $[35,36]$ only 3 months of lifestyle modification was shown to result in an increase in exercise duration, total work performed, left ventricular regional wall motion during peak exercise, and quality of life. This was accompanied by a decrease in plasma cholesterol levels and a reduction in angina frequency. Most improvements were maintained over 12 months. In agreement with the results of studies, Manchanda et al. $[37,38]$ conducted studies in CHD patients and observed a significant improvement with yoga practice in the number of angina attacks, body weight and ST segment depression during exercise, as well as less progression of coronary atherosclerosis in patients with established CHD. Pullen et al. [39] randomized 40 patients (38 African-Americans) with systolic or diastolic heart failure to the yoga group or the control group. All patients were asked to follow a walking program. Yoga therapy in this study offered additional benefits to the standard medical care of predominantly African-Americans heart failure patients by improving cardiovascular endurance, quality of life, inflammatory markers, and flexibility.

A host of other studies Table 3 have documented regression of coronary atherosclerosis and the extent of myocardial ischemia. While the measurement of coronary luminal narrowing would suggest enhanced blood flow, there is ample evidence that the practice of yoga can reduce the determinants of myocardial oxygen demand, such as blood pressure, heart rate, respiratory rate and catecholamine release $[3,39,40]$.

Of note, in contrast to the results of these studies showing salutary effect of yoga and intensive life-style modification, Aldana et al. [29] were not able to show the beneficial effect of intensive lifestyle modification program for 1 year on carotid artery intimamedia thickness measured by ultrasonography. Sivasankaran et al. [41] studied modulation of vascular tone as a surrogate of vascular health by yoga. Subjects practiced yoga for 1.5 hours 3 times a week for 6 weeks, and additional sessions at home on their own. Regular practice of yoga led to a significant reduction in heart rate, body mass index and blood pressure. Importantly, the improvement in brachial artery reactivity was identified only in patients with documented CHD, implying improvement in endothelium-dependent relaxation only when it is impaired.

Overall, it appears that the salutary effects of yoga on cardiac hemodynamic profile and vasoreactivity become manifest as early as 1 month, whereas the measurable reduction in coronary atherosclerosis takes about a year. 
Yoga in patients with metabolic syndrome and/or diabetes mellitus

Major trials of yoga in patients with metabolic syndrome and/ or diabetes are summarized in Table 4. Anderson and Taylor have recently provided an elegant review of the role of midbody therapy on the metabolic syndrome [41,42]. Cohen et al. [43] studied 50 subjects with metabolic syndrome; of these 26 men and women were randomized to practice 15 yoga sessions of 90 minutes each over 10 weeks. Subjects who practiced yoga felt that exercises were easy to perform, and reported an increase in energy and improvement in quality of life, and their blood pressure trended to fall. Singh et al. [44] studied 24 patients with type 2 diabetes mellitus; the subjects were trained in yoga asanas (postures) for 30-40 minutes each day for 40 days. The asanas were performed in a sequence. After 40 days, the authors noted significant reductions in fasting blood sugar; heart rate, systolic and diastolic blood pressures, and body weight of patients.

Table 4: Effect of yoga in patients with diabetes mellitus or metabolic syndrome.

\begin{tabular}{|c|c|c|}
\hline Single arm [25] & $\begin{array}{c}\text { Asanas, pranayamas } \\
\text { relaxation and group } \\
\text { support for 10 days }\end{array}$ & $\begin{array}{c}\text { Improvements in } \\
\text { lipids and blood sugar } \\
\text { in yoga group }\end{array}$ \\
\hline RCT [42] & $\begin{array}{c}\text { 15 Yoga sessions over } \\
\text { 10 weeks vs. controls } \\
\text { (no intervention) }\end{array}$ & $\begin{array}{c}\text { Yoga group had } \\
\text { significant increase in } \\
\text { energy, but no change } \\
\text { in blood pressure or } \\
\text { stress }\end{array}$ \\
\hline RCT [52] & $\begin{array}{c}\text { Yoga classes for } \\
\text { 12 weeks vs. no } \\
\text { intervention in } \\
\text { patients with type } \\
2 \text { DM }\end{array}$ & $\begin{array}{c}\text { Compliance was low } \\
\text { and no changes in } \\
\text { HbA1c }\end{array}$ \\
\hline
\end{tabular}

Hypertension, dyslipidemia and diabetes often co-exist. Bijlani et al. [26] enrolled 98 subjects, 67 males and 31 females, age 2074 years; all had hypertension, diabetes and CHD. They found that the practice of yoga [asanas (postures), pranayamasa (breathing), relaxation techniques, group support, meditation, stress management, knowledge of nutrition] lowered blood pressure, fasting plasma glucose and serum lipoproteins with the first session of yoga practice. As the practice of yoga continued, there was a significant improvement in plasma levels of fasting glucose, total- and LDL-cholesterol, triglycerides, and HDL-cholesterol, especially in individuals who started out with elevated glucose and/or LDL-cholesterol levels. Bera \& Rajapurkar [45] evaluated the impact of yoga practice on body composition, cardiovascular endurance and anaerobic power in 40 healthy students, 20 assigned to yoga group and 20 served as control. After 1 year, there was a significant improvement in body weight, body density, exercise endurance and anaerobic performance in the yoga group compared to the control group. There was a decrease in body fat, and the fat folds were notably less in the yoga group.

Yoga also improves blood coagulation. Chohan et al. [46] evaluated the effects of the practice of yoga on blood coagulation, and found that yoga practice enhanced fibrinolytic activity, and increased plasma thromboplastin time and platelet aggregation time, while platelet counts and hemoglobin levels increased. Hatha yoga performed in a more intense fashion than usual may be able to change cardiovascular risk factors. Ramos Jimenez et al. [40] evaluated 4 middle aged and 9 older yoga practitioners in an 11-week intensive hatha yoga program with 5 sessions per week for 90 minutes. The practice of hatha yoga increased VO2 max and VE max and HDL-cholesterol levels, while triglycerides and LDLcholesterol levels remained stable.

\section{Yoga in special populations}

Elderly are the fastest growing group in the US, Europe and Japan. This group experiences the vast burden of hypertension, diabetes mellitus and CHD. These patients generally have a sedentary life-style. Yoga is easy to implement in the elderly and helps achieve fitness. Further, the elderly who may not be able to tolerate vigorous exercise routine may be able to practice yoga as the exercises are gentle [46-48]. Chen et al. [49] evaluated physical fitness of elderly individuals after 24 week 3 -times a week of the silver yoga program, developed for the elderly. Of the 204 individuals enrolled in the study and randomly assigned either to the silver yoga with gentle stretching and meditation, meditation alone, or to a wait list (control group), 176 finished the study. They found that individuals in the first and second groups improved their physical fitness level compared to those in the control group.

Clay et al. [50] evaluated if hatha yoga would alter body's metabolism and heart rate in 26 women (19-40 years of age) who were taught to practice yogic postures for 30 minutes a day for 2 months. There were no significant differences in the markers of metabolism or in maximal heart rate in these women. Overall, the hatha yoga practice was equivalent to light intensity walking in young women. Pullen et al. [39] evaluated if yoga practice would benefit African Americans with heart failure. People in the yoga group had statistically significant improvements in flexibility, treadmill time, VO2 peak, plasma levels of interleukin-6, C-reactive protein and extracellular superoxide dismutase, as well as in quality of life scales. Cade et al. [51] evaluated 60 adults with CHD risk factors and HIV infection and assigned them to 20 weeks of yoga or standard care. They observed that resting systolic and diastolic blood pressures were improved in the yoga group, but other parameters, such as CD4 counts, remained unchanged and similar in both groups.

\section{Yoga retreats}

Most yoga training is performed in class rooms, and each session lasts 30 to 90 minutes, sessions are conducted 3 to 7 days per week, and the subjects are advised to practice yoga at home at least once daily. While some benefits may appear early, the most pronounced effects are seen after years of regular practice. Living in yoga retreats may be even more beneficial than attending intermittent sessions. Schmidt and colleagues [20] evaluated cardiovascular risk factors in subjects who stayed in a yoga training center. The participants had only vegetarian nutrition. Following 
3 months of stay in yoga retreat, there was a significant reduction in body mass index, total- and LDL-cholesterol, fibrinogen and blood pressure, especially in those with elevated levels.

\section{Side effects of yoga practice}

One of the reasons for advocating yoga to patients is low risk of side effects, when yoga is performed in moderation. Although most patients do well, appropriate yoga requires proper training and guidance. However, there are some issues that need some attention. For example, aggressive and sudden changes in yoga postures may be stressful. Accordingly, vigorous yoga practice should be avoided in the elderly or people with high ocular pressure disorders. Some breathing techniques result in cessation or retention of breath-these should be avoided in patients with cardiac or lung disease.

Several cardiovascular specific side-effects have been reported. For example, a patient developed vertebral artery occlusion after neck manipulations during yoga practice [52]. Patients with hypertension or CHD should avoid shoulder standing exercises that flex the neck to avoid neck arterial damage. These patients should also avoid inverted asana (shoulder stand and head stand). Patients with heart or lung problems should avoid exercises that cause pain or stress. Most importantly, patients with any disease should not rely on practice of yoga instead of standard medical practice; rather the two approaches should be used together for a complementary effect.

\section{Summary of the effects of Yoga on Cardiovascular System}

Yoga has been established as an effective means to improve overall health especially in patients suffering from stress, hypertension, coronary atherosclerosis, heart failure, dyslipidemia, diabetes, anxiety, depression and other similar conditions. It is obvious that the regular practice of yoga, particularly when combined with other life-style modifications, can induce biochemical alterations that have a salutary effect of cardiac hemodynamics, blood lipids, fasting blood sugar, body mass, and thought process. However, there are very few randomized controlled studies on the beneficial effects of yoga. Nonetheless, the effects of yoga practice seem quite impressive in patients with hypertension [21-23] and in patients with CHD in which regression of coronary atherosclerosis was demonstrated [33-36]. Further, it appears that yoga practice is generally free of side-effects in most cases and has a favorable cost benefit ratio. Most of the studies conducted thus far have been in a small number of patients. Further, there are differences in type of yoga practiced with or without meditation. Thus comparing and interpreting the multitude of studies of yoga in subjects who have varied risk factors such as hypertension, diabetes and CHD present major challenge.

Many studies have combined several features of life-style modification, such as low calorie, low fat diet, smoking cessation and stress reduction programs. It is well recognized that lifestyle modification has a major effect of vascular tone, lipid levels, and overall health. Whether the practice of yoga complements the effects of lifestyle modification cannot be discerned from these studies. There is also publication bias in that the studies that show a beneficial effect are submitted for publication more often and are more likely to be published than the studies that showed no beneficial effect of a given therapy. Lastly, it must be acknowledged that there cannot be a true control group in clinical trials. Patients know when they are performing yoga and meditation. Using "mock" yoga therapy (for example, breathing deeply, or meditation or relaxation training) also has therapeutic effect. A beneficial effect of yoga could be masked if the control group shows beneficial effect. Importantly, there is no way to 'blind' patients, since the practice is unblinded by involving participation of the subject.

\section{References}

1. Grippo AJ, Johnson AK (2009) Stress, depression and cardiovascular dysregulation: a review of neurobiological mechanisms and the integration of research from preclinical disease models. Stress 12(1): $1-21$.

2. Clarke TC, Black LI, Stussman BJ, Barnes PM, Nahin RL (2015) Trends in the use of complementary health approaches among adults: United States, 2002-2012. Natl Health Stat Report (79): 1-16.

3. Jayasinghe SR (2004) Yoga in cardiac health (a review). Eur J Cardiovasc Prev Rehabil 11(5): 369-375.

4. Nayak NN, Shankar K (2004) Yoga: a therapeutic approach. Phys Med Rehabil Clin N Am 15(4): 783-798.

5. Sheridan DJ, Penkoske PA, Sobel BE, Corr PB (1980) Alpha adrenergic contributions to dysrhythmia during myocardial ischemia and reperfusion in cats. J Clin Invest 65(1): 161-171.

6. Lanza GA, Giordano A, Pristipino C, Maria Lucia Calcagni, Guido Meduri, et al. (1997) Abnormal cardiac adrenergic nerve function in patients with syndrome $\mathrm{X}$ detected by $\left[{ }^{123} \mathrm{I}\right]$ metaiodobenzylguanidine myocardial scintigraphy. Circulation 96: 821-826.

7. Kono T, Morita H, Kuroiwa T, Onaka H, Takatsuka H, et al. (1994) Left ventricular wall motion abnormalities in patients with subarachnoid hemorrhage: neurogenic stunned myocardium. J Am Coll Cardiol 24(3): 636-640.

8. Astin JA, Shapiro SL, Eisenberg DM, Forys KL (2003) Mind-body medicine: state of the science, implications for practice. J Am Board Fam Pract 16(2): 131-147.

9. Jevning R, Wallace RK, Beidebach M (1992) The physiology of meditation: a review. A wakeful hypometabolic integrated response. Neurosci Biobehav Rev 16(3): 415-424.

10. Bremner JD (2001) Hypotheses and controversies related to effects of stress on the hippocampus: an argument for stress-induced damage to the hippocampus in patients with posttraumatic stress disorder. Hippocampus 11(2): 75-81.

11. Bremner J (1999) Does stress damage the brain? Biol Psychiatry 45(7): 797-805.

12. Bremner JD (1999) Alterations in brain structure and function associated with post-traumatic stress disorder. Semin Clin Neuropsychiatry 4(4): 249-255.

13. Damodaran A, Malathi A, Patil N, Shah N, Suryavansihi, et al. (2002) Therapeutic potential of yoga practices in modifying cardiovascular risk profile in middle aged men and women. J Assoc Physicians India 50(5): 633-640.

14. Selvamurthy W, Sridharan K, Ray US, Tiwary RS, Hegde KS, et al. (1998) A new physiological approach to control essential hypertension. Indian J Physiol Pharmacol 42(2): 205-213. 
15. Harinath K, Malhotra AS, Pal K, Prasad R, Kumar R, et al. (2004) Effects of Hatha yoga and Omkar meditation on cardiorespiratory performance, psychologic profile, and melatonin secretion. J Altern Complement Med 10(2): 261-268.

16. Rai UCSS, Singh SH (1997) Some effects of Sahaja Yoga and its role in the prevention of stress disorders. New Delhi Medicos 13: 35-38.

17. Mishra RBC, Barone D (1993) Plasma beta-endorphin levels in humans: Effect of Sahaja Yoga. Paper presented at the Medical Aspects of Sahaja Yoga. Transpersonal Psychology Review 4: 41-49.

18. Rai UC SS, Singh SH (1988) Some effects on Sahaja Yoga and its role in the prevention of stress disorders. Journal Int Med Sci 1: 9-23.

19. Innes KE, Bourguignon C, Taylor AG (2005) Risk indices associated with the insulin resistance syndrome, cardiovascular disease, and possible protection with yoga: a systematic review. J Am Board Fam Pract 18(6): 491-519

20. Schmidt T, Wijga A, Von ZurMuhlen A, Brabant G, Wagner TO (1997) Changes in cardiovascular risk factors and hormones during a comprehensive residential three month kriya yoga training and vegetarian nutrition. Acta Physiol Scand Suppl 640: 158-162.

21. Patel C (1975) Yoga and biofeedback in the management of 'stress' in hypertensive patients. Clin Sci Mol Med Suppl 2: 171s-174s.

22. Patel C (1975) 12-month follow-up of yoga and bio-feedback in the management of hypertension. Lancet 1(7898): 62-64.

23. Patel C, North WR (1975) Randomised controlled trial of yoga and biofeedback in management of hypertension. Lancet 2(7925): 93-95.

24. Vyas R, Dikshit N (2002) Effect of meditation on respiratory system, cardiovascular system and lipid profile. Indian J Physiol Pharmacol 46(4): 487-491.

25. Murugesan R, Govindarajulu N, Bera TK (2000) Effect of selected yogic practices on the management of hypertension. Indian J Physiol Pharmacol 44(2): 207-210.

26. Bijlani RL, Vempati RP, Yadav RK, Ray RB, Gupta V, et al. (2005) A brief but comprehensive lifestyle education program based on yoga reduces risk factors for cardiovascular disease and diabetes mellitus. J Altern Complement Med 11(2): 267-274.

27. Govil SR, Weidner G, Merritt Worden T, Ornish D (2009) Socioeconomic status and improvements in lifestyle, coronary risk factors, and quality of life: the multisite cardiac lifestyle intervention program. Am J Public Health 99(7): 1263-1270.

28. Frattaroli J, Weidner G, Merritt Worden TA, Frenda S, Ornish D (2008) Angina pectoris and atherosclerotic risk factors in the multisite cardiac lifestyle intervention program. Am J Cardiol 101(7): 911-918.

29. Aldana SG, Greenlaw R, Salberg A, Merrill RM, Hager R, et al. (2007) The effects of an intensive lifestyle modification program on carotid artery intima-media thickness: a randomized trial. Am J Health Promot 21(6): 510-516

30. Danucalov MA, Simoes RS, Kozasa EH, Leite JR (2008) Cardiorespiratory and metabolic changes during yoga sessions: the effects of respiratory exercises and meditation practices. Appl Psychophysiol Biofeedback 33(2): 77-81.

31. Aldana SG, Whitmer WR, Greenlaw R, Avins AL, Thomas D, et al. (2006) Effect of intense lifestyle modification and cardiac rehabilitation on psychosocial cardiovascular disease risk factors and quality of life. Behav Modif 30(4): 507-525.

32. Aldana SG, Greenlaw R, Thomas D, Salberg A, DeMordaunt T, et al (2004) The influence of an intense cardiovascular disease risk factor modification program. Prev Cardiol 7(1): 19-25.

33. Aldana SG, Whitmer WR, Greenlaw R, Avins AL, Salberg A, et al. (2003) Cardiovascular risk reductions associated with aggressive lifestyle modification and cardiac rehabilitation. Heart Lung 32(6): 374-382.
34. Billings JH (2000) Maintenance of behavior changes in cardiorespiratory risk reduction: a clinical perspective from the Ornish Program for reversing coronary heart disease. Health Psychol 19(1S): 70-75.

35. Ornish D, Brown SE, Scherwitz LW, Billings JH, Armstrong WT, et al (1990) Can lifestyle changes reverse coronary heart disease? The Lifestyle Heart Trial. Lancet 336(8708): 129-133.

36. Ornish D, Scherwitz LW, Doody RS, Kesten D, McLanahan SM, et al. (1983) Effects of stress management training and dietary changes in treating ischemic heart disease. JAMA 249(1): 54-59.

37. Manchanda SC, Narang R, Reddy KS, Sachdeva U, Prabhakaran D, et al. (2000) Retardation of coronary atherosclerosis with yoga lifestyle intervention. J Assoc Physicians India 48(7): 687-694.

38. Manchanda SC, Narang R (1998) Yoga and coronary artery disease. Indian Heart J 50: 227-228.

39. Pullen PR, Thompson WR, Benardot D, Brandon LJ, Mehta PK, et al. (2010) Benefits of yoga for African American heart failure patients. Med Sci Sports Exerc 42(4): 651-657.

40. Ramos Jimenez A, Hernandez Torres RP, Wall Medrano A, Munoz Daw M, Torres Duran PV, et al. (2009) Cardiovascular and metabolic effects of intensive Hatha Yoga training in middle-aged and older women from northern Mexico. Int J Yoga 2(2): 49-54.

41. Sivasankaran S, Quintner SP, Sachdeva R, Pugeda J, Hoq SM, et al. (2006) The effect of a six-week program of yoga and meditation on brachial artery reactivity: do psychosocial interventions affect vascular tone? Clin Cardiol 29(9): 393-398.

42. Anderson JG, Taylor AG (2011) The metabolic syndrome and mindbody therapies: a systematic review. Journal of Nutrition and Metabolism 2011(2011): 1-8.

43. Cohen BE, Chang AA, Grady D, Kanaya AM (2008) Restorative yoga in adults with metabolic syndrome: a randomized, controlled pilot trial. Metab Syndr Relat Disord 6(3): 223-229.

44. Singh S, Malhotra V, Singh KP, Madhu SV, Tandon OP (2004) Role of yoga in modifying certain cardiovascular functions in type 2 diabetic patients. J Assoc Physicians India 52: 203-206.

45. Bera TK, Rajapurkar MV (1993) Body composition, cardiovascular endurance and anaerobic power of yogic practitioner. Indian J Physiol Pharmacol 37(3): 225-228.

46. Chohan IS, Nayar HS, Thomas P, Geetha NS (1984) Influence of yoga on blood coagulation. Thromb Haemost 51(2): 196-197.

47. Schneider RH, Alexander CN, Salerno JW, Robinson DK, Fields JZ, et al. (2002) Disease prevention and health promotion in the aging with a traditional system of natural medicine: Maharishi Vedic Medicine. J Aging Health 14(1): 57-78.

48. Luskin FM, Newell KA, Griffith M, Holmes M, Telles S, et al. (1998) A review of mind-body therapies in the treatment of cardiovascular disease. Implications for the elderly. Altern Ther Health Med 4(3): 4661.

49. Chen KM, Fan JT, Wang HH, Wu SJ, Li CH, et al. (2010) Silver yoga exercises improved physical fitness of transitional frail elders. Nurs Res 59(5): 364-370.

50. Clay CC, Lloyd LK, Walker JL, Sharp KR, Pankey RB (2005) The metabolic cost of hatha yoga. J Strength Cond Res 19(3): 604-610.

51. Cade WT, Reeds DN, Mondy KE, Overton ET, Grassino J, et al. (2010) Yoga lifestyle intervention reduces blood pressure in HIV-infected adults with cardiovascular disease risk factors. HIV Med 11(6): 379 388 .

52. Hanus SH, Homer TD, Harter DH (1977) Vertebral artery occlusion complicating yoga exercises. Arch Neurol 34(9): 574-575. 

(CC) $\begin{aligned} & \text { This work is licensed under Creative } \\ & \text { Commons Attribution 4.0 License } \\ & \text { DOI: } 10.19080 / J Y P .2017 .02 .555604\end{aligned}$
Your next submission with Juniper Publishers will reach you the below assets

- Quality Editorial service

- Swift Peer Review

- Reprints availability

- E-prints Service

- Manuscript Podcast for convenient understanding

- Global attainment for your research

- Manuscript accessibility in different formats ( Pdf, E-pub, Full Text, Audio)

- Unceasing customer service

Track the below URL for one-step submission https://juniperpublishers.com/online-submission.php 